\title{
The efficacy of erlotinib as molecularly targeted maintenance therapy in advanced non-small-cell lung cancer (NSCLC): Case reports in western I ran
}

\author{
Mehrdad Payandeh ${ }^{1}$, Reza Khodarahmi ${ }^{2}$, Masoud Sadeghi ${ }^{2}$, Edris Sadeghi ${ }^{3}$ \\ 1. Department f Hematology-Oncology, Kermanshah University of Medical Sciences, Iran, Islamic Republic Of. 2. Medical \\ Biology Research Center, Kermanshah University of Medical Sciences, I ran, I slamic Republic Of. 3. Department of Nursing, \\ Borujerd Branch, Islamic Azad University, Borujerd, Iran, Islamic Republic Of.
}

Correspondence: Masoud Sadeghi. Address: Medical Biology Research Center, Kermanshah University of Medical Sciences, Iran, Islamic Republic Of. Email: sadeghi_mbrc@yahoo.com

Received: July 1, 2014

DOI : $10.5430 /$ jst.v4n3p38
Accepted: October 9, 2014

Online Published: October 24, 2014

URL: http://dx.doi.org/10.5430/jst.v4n3p38

\section{Abstract}

In developing countries, majority of cancer patients have low income. Therefore, we could hardly do maintenance therapy about the number of patients with non-small-cell lung cancer and other cancers. Maintenance therapy for advanced non-small-cell lung cancer (NSCLC) refers to the use of an effective agent in the absence of disease progression following platinum-based combination chemotherapy to improve progression-free survival. In our Clinic, we identified three cancerous patients with metastasis for lung cancer. The Epidermal Growth Factor Receptor mutation on exon 19 started erlotinib therapy for several courses. After a short time, in all patients, lesions decreased and patients became stable.

\section{Key words}

Brain blood barrier, EGFR mutation, Maintenance therapy, NSCLC, TTF-1

\section{I ntroduction}

Lung cancer is one of the leading causes of death in the world, and non-small cell lung carcinoma accounts for approximately $75 \%-85 \%$ of all lung cancers ${ }^{[1]}$. Maintenance therapy for advanced non-small-cell lung cancer (NSCLC) refers to the use of an effective agent in the absence of disease progression following platinum-based combination chemotherapy to improve progression-free survival (PFS) and overall survival. This type of intervention is continued for a determined period of time unless there is disease progression or significant toxicities develop ${ }^{[2]}$. Epidermal growth factor receptor (EGFR) tyrosine kinase inhibitors (TKIs), such as erlotinib, have been extensively investigated in previously treated advanced NSCLC ${ }^{[3]}$, and in our cases it is clear the efficacy of (EFGR-TKI: erlotinib) in as molecularly targeted maintenance therapy in advanced non-small-cell lung cancer (NSCLC) ${ }^{[3]}$.

Vincenten $\mathrm{J}$ et al. ${ }^{[4]}$ reported that thyroid transcription factor-1 (TTF-1) associated with the presence of EGFR mutations in NSCLC patients. 
In this study, we describe three patients with metastasis of NSCLC who was treated with maintenance therapy by erlotinib. Also, this study may explains the overall situation of NSCLC cancer patients in the western Iran and more importantly define that TTF-1 and EGFR mutation were effective diagnostic factors in metastasis of NSCLC. MTOR inhibitors in combination with chemotherapy have been found to be additive or synergistic. Compared with single agent therapy, the combination of rapamycin with chemotherapy enhances apoptosis in vitro and enhances anti tumor efficacy in vivo ${ }^{[5-7]}$.

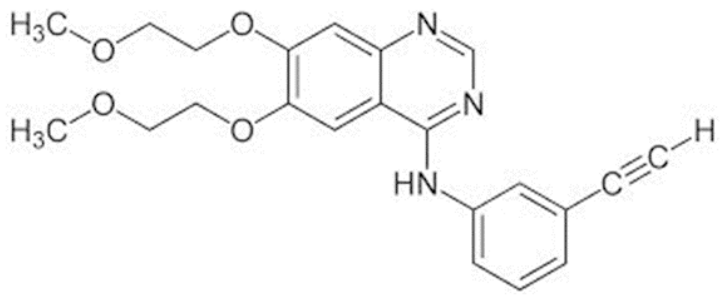

Figure 1. Chemical structure of erlotinib.

\section{Case reports}

Case A: In March 2012, a 58-year-old man referred to Clinic of Neurology with headache, seizure and right facial weakness with a history of smoking. The MRI of his brain showed brain's lesions (see Figure 2A). Stereotactic surgery and biopsy were performed, too. In his pathological report, poorly differentiated carcinoma had been confirmed. Moreover, Immunohistochemistry (IHC) showed metastatic adenocarcinoma in brain. The results of markers showed CD20 and CD45 were negative, but (epithelial membrane antigen) EMA, cytokeratin 7(CK7) and TTF-1 were well positive. It was clear that brain metastasis is due to appearance of primary lung cancer. Due to lower safe of brain lesions ( $<3$ lesions), Gamma Knife radiosurgery was performed for him. He was treated with 4 courses of combination chemotherapy. The EGFR mutation with exon 19 deletion was documented for him. Two months after start of the chemotherapy, results were positive, and he was eligible for TK inhibitor (erlotinib) therapy. After 4 months of erlotinib monotherapy, no lesion was observed in brain MRI and all of them had been resolved (see Figure 2B). The patient was then treated for one year with combination of erlotinib (TK inhibitor) + sirolimus (mTOR inhibitor) + temodar (topoisomerase inhibitor). Unfortunately, 16 months after treatment of combination therapy, the patient suffered of dyspnea. In lung CT, apicoposterior segment lesion of left upper lobe was detected. Again, he was treated with secondary single chemotherapy, for 3 months. Respiratory complaint regressed and lung lesion not progressed. In March 2014, he died with sudden cerebrovascular accident (CVA).

Case B: A 68-year-old woman referred to Clinic of Oncology with cough without a history of smoking. Her image was evaluated. Whole body isotopic bone scan were positive for metastasis. In CT spiral scan of whole body, several randomly distributed pulmonary parenchymal nodules were detected (see Figure 3A). Following CT guided core biopsy; a poorly differentiated/metastatic adenocarcinoma in left lung was detected. In IHC evaluation, TTF-1 was positive. In EGFR mutation analysis, "exon19 deletion" was detected. Regarding this diagnosis, she was eligible to EGFR-TK (erlotinib) therapy. Three months after beginning of erlotinib therapy, lung nodules significantly decreased (see Figure 3B). At now, after 24 months she is stable and all of lung lesions have disappeared and also in bone scan, lesions were sclerosed (see Figure 3B, arrows).

Case C: A 47-year-old woman referred to Clinic of Oncology with complaint of progression dyspnea and weight loss with generalized bone pain without a history of smoking. In evaluation of imagine of her chest CT scan, moderate degree of right pleural effusion with small thickness in anterior portion of pleural, and small lesion at level of RML-lower lobe of bronchi were detected (Figure 4A). In abdominal CT scan a hypodense $(19 \times 22 \mathrm{~mm})$ lesion, with extension to 
periampullary area of pancreas, was detected. Pleural cytology and biochemical analysis reported inflammatory reaction with lymphocyte predominant. Analyses of her pleural biopsy showed that she suffer from metastatic adenocarcinoma with papillary features. In whole body, isotopic bone metastatic was detected although genitourinary, breasts and thyroid were normal.

In IHC assessments, TTF-1 and CK7 were positive while CK2, CK5/6, CK20, calretinin, ER, PR were negative. In final report/diagnosis, metastatic adenocarcinoma with lung origin was recommended. The paraffin block was evaluated for any changes in exons 18 to 21, and insertional change in exon 19 (as heterozygous) and EGFR mutation was detected. Then, based on this pathology analysis, she was eligible for therapy with EGFR kinase inhibitor. She was treated with erlotinib ( $150 \mathrm{mg} /$ day $)$, and after 3 months of treatment all complaints of patient reduced and in imaging evaluation, all of lesions decreased more than 50\% (see Figure 4B). At now, she is stable, and this policy will be continued for her.
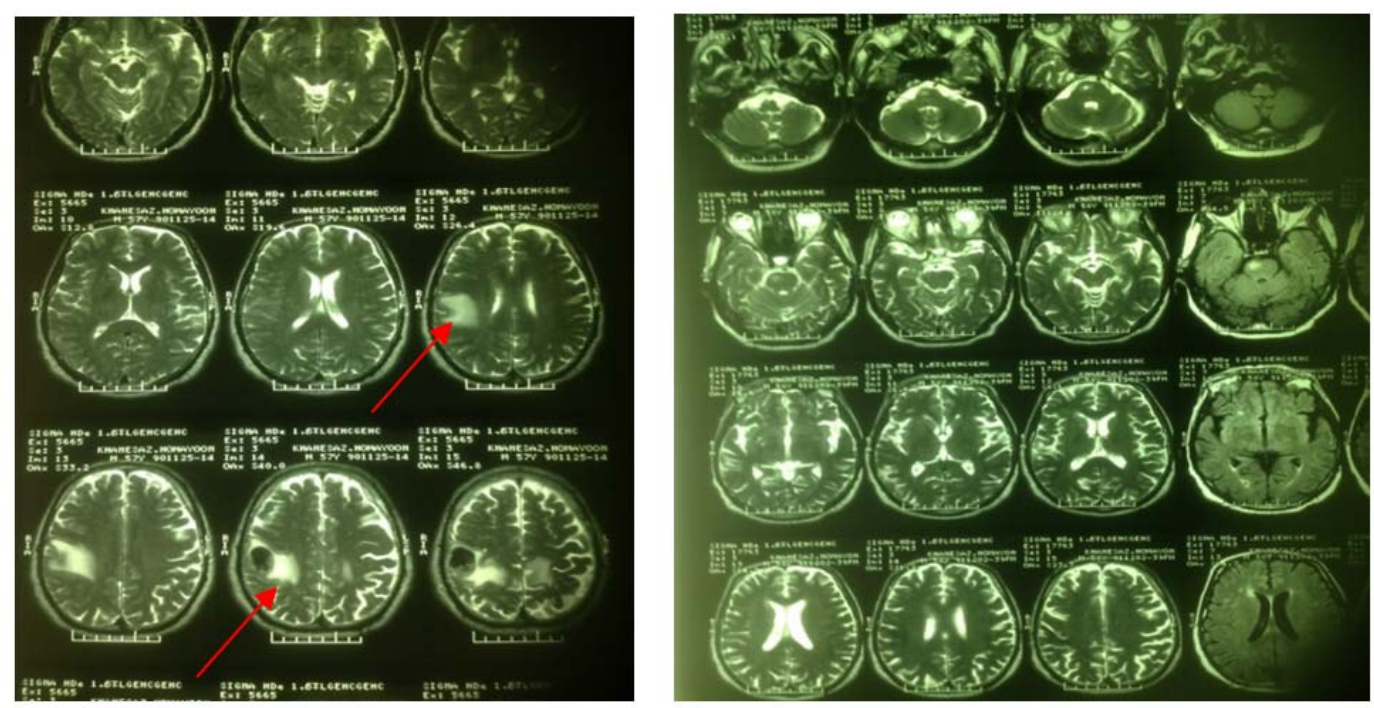

Figure 2. MRI of brain (A) before (B) after erlotinib therapy. A March 2012, B January 2013. Arrows show the tumor (lesion) which has proved to be metastatic adenocarcinoma.
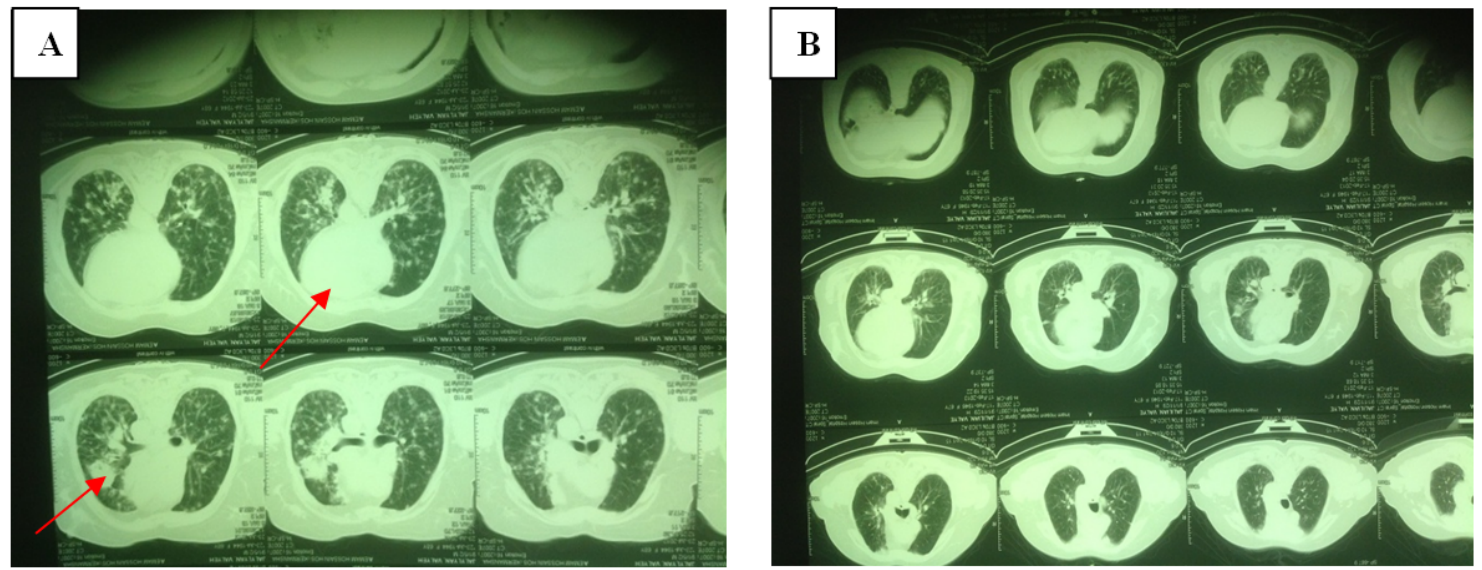

Figure 3. CT scan of Lung (A) before (B) after erlotinib therapy. A July 2012, B February 2013. Arrows show lung lesions improved compared with previous lung $\mathrm{CT}$ of patient. 


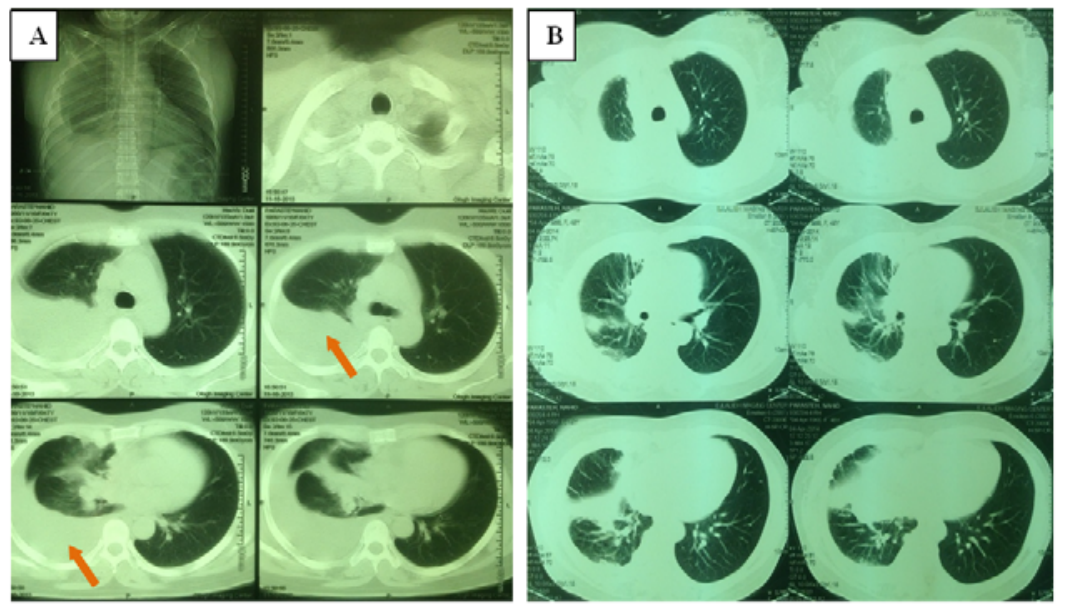

Figure 4. CT scan of Lung (A) before (B) after erlotinib therapy. A December 2013, B April 2014. Arrows show the tumor (lesion) which has proved to be metastatic adenocarcinoma with lung origin.

\section{Discussion}

Our department of oncology is in Kermanshah province, which is one of western provinces in IRAN, and neighbor with Iraq country. In 2009, a study ${ }^{[8]}$ showed that health care payments in western Iran, compared with other developing countries in Asia, are very high. Majority of peoples this province and surrounding provinces are rural and living in (IRAN-IRAQ) war zone. In 2012, Rostaei S et al. ${ }^{[9]}$ reported that $43 \%$ of people in Kermanshah city are below the poverty line. Therefore, majority of cancer patients may have low income ( $\$ 35$ - $\$ 150$ per month). In recent years, due to sanctions on Iran, and since majority of patient samples should be sent to Tehran (capital of Iran) for further evaluation, diagnosis, treatment and drug costs have had a huge increase. Despite financial limitations for majority of patients, because of appropriate clinical facilities in Kermanshah province compared to the neighboring provinces, the number of patients referred to our clinic is very high, and over a few past years we could do maintenance therapy for the number of wealthy cancer patients. In this way, so we could stable lung cancer for three patients (top case reports).

Fortunately during last recent five years Erlotinib registered and available, that facilitate patient treatment policy. EGFR is a member of the type I growth factor receptor family, and The EGFR gene is located in chromosome 7 in the short arm TP12-14 district ${ }^{[10]}$. The epidermal growth factor receptor (EGFR) is a transmembrane glycoprotein that constitutes one of four members of the erbB family of tyrosine kinase receptors ${ }^{[11]}$. In the vast majority of cases, EGFR mutations are non-overlapping with other oncogenic mutations found in NSCLC (e.g., KRAS mutations, ALK rearrangements, etc.). More than $90 \%$ of EGFR mutations are located in the exons 18 to 21, and the most common mutations lie in exons 19 and $21^{[12]}$. In EGFR gene, exons 18-21 are analyzed in tumor-derived DNA ${ }^{[13]}$.

Exon 19 deletion mutations occur in a protein strand (called the $\beta 3$ strand) adjacent to the C-helix. Similarly, the exon 19 insertion mutations all lead to substitution of residue L $747^{[14]}$. In three listed cases, EGFR mutation happened in exon 19, and erlotinib consumption improved metastasis in all of them. So may be patients with exon 19 (deletion/insertion) respond more positively to erlotinib compared with 18 or 21. In future researches is better that this point be considered. This study showed that erlotinib was effective in the elderly patients in this case series. Although this report includes a small number of patients, but it demonstrates that erlotinib can be a suitable treatment for lung cancer patients in conditions that patients can't take expensive drugs.

One series found PIK3/CA mutations in 5\% of cases of acquired resistance ${ }^{[15]}$, and several trials combining EGFR TKIs with PI3K inhibitors are underway ${ }^{[16]}$. 
A retrospective study has also show higher response rates in setting when chemotherapy is given with a TKI ${ }^{[17]}$.

In a randomized study conducted in the first-line setting, erlotinib plus chemotherapy was found to be somewhat more toxic than chemotherapy, but no antagonism was seen; afficacy was equal in patients with untreated EGFR-mutant lung cancer $^{[18]}$.

Thyroid transcription factor-1 (TTF-1) is a 38-kDa nuclear protein initially identified as a mediator of thyroid-specific gene transcription ${ }^{[19]}$. TTF-1 is a member of the NKX2-1 family; it is expressed in the thyroid, forebrain, lung and other organs, and is a sensitive marker for pulmonary and thyroid adenocarcinomas ${ }^{[20]}$. Results of Lee JS et al ${ }^{[21]}$. showed that TTF-1 amplification might be a predictive marker of poor response to EGFR-TKI therapy in patients with recurrent tumor after surgical resection. Vallee A et al. ${ }^{[22]}$ reported that EGFR mutation rate was much higher in tumors expressing the TTF-1 antigen than in TTF-1 negative tumors. Also, a study ${ }^{[23]}$ reported that erlotinib may to cross the blood-brain barrier, and other study ${ }^{[24]}$ on patients who underwent whole-brain radiotherapy demonstrated that this procedure may increase the permeability of the blood-brain barrier and eventually lead to a change in the erlotinib concentration in the cerebrospinal fluid. Togashi $Y$ et al. ${ }^{[25]}$ suggested that $150 \mathrm{mg}$ daily erlotinib can increase concentration of erlotinib in cerebrospinal fluid, so erlotinib could be effective for the treatment of central nervous system (CNS) metastases of NSCLC. Of three listed patients, one patient had lung cancer with metastasis of brain. Consumption of erlotinib in patients led to improved of metastasis. It is probably that erlotinib could cross of BBB. Confirmation of this hypothesis needs to more comprehensive studies.

Results of the study suggested that first of all, these case reports show that maintenance therapy with erlotinib according to molecular markers (TTF-1 and kind of EGFR mutation) can help survival rate in patients. Second, in this report illustrates erlotinib may to cross the blood-brain barrier.

\section{Acknowledgement}

The authors thank to company of AqVida GmbH, Hamburg (Hamburg, Germany) for their financial support.

\section{References}

[1] Yoo J, Lee SH, Lym KI, Park SY, Yang SH, Yoo CY, et al. Immunohistochemical Expression of DCUN1D1 in Non-small Cell Lung Carcinoma: Its Relation to Brain Metastasis. Cancer Res Treat. 2012 Mar; 44(1): 57-62. PMid:22500162 http://dx.doi.org/10.4143/crt.2012.44.1.57

[2] Klein R, Wielage R, Muehlenbein C, Liepa AM, Babineaux S, Lawson A, et al. Cost-effectiveness of pemetrexed as first-line maintenance therapy for advanced nonsquamous non-small cell lung cancer. J Thorac Oncol. 2010; 5: $1263-1272$. PMid:20581708 http://dx.doi.org/10.1097/JTO.0b013e3181e15d16

[3] Yang X, Yang K, Kuang K. The Efficacy and Safety of EGFR Inhibitor Monotherapy in Non-Small Cell Lung Cancer: A Systematic Review. Curr Oncol Rep. 2014 Jun; 16(6): 390. PMid:24807015 http://dx.doi.org/10.1007/s11912-014-0390-4

[4] Vincenten J, Smit EF, Vos W, Grünberg K, Postmus PE, Heideman DA, et al. Negative NKX2-1 (TTF-1) as temporary surrogate marker for treatment selection during EGFR-mutation analysis in patients with non-small-cell lung cancer. J Thorac Oncol. 2012 Oct; 7(10): 1522-7. PMid:22982653 http://dx.doi.org/10.1097/JTO.0b013e3182635a91

[5] Mondesire WH, Jian W, Zhang H, et al: Targeting mammalian target of rapamycin synergis- tically enhances chemotherapy-induced cytotoxicity in breast cancer cells. Clin Cancer Res. 2004; 10: 7031- 7042. PMid:15501983 http://dx.doi.org/10.1158/1078-0432.CCR-04-0361

[6] Steelman LS, Navolanic PM, Sokolosky ML, et al. Suppression of PTEN function increases breast cancer chemotherapeutic drug resistance while con- ferring sensitivity to mTOR inhibitors. Oncogene. 2008; 27: 4086-4095. PMid:18332865 http://dx.doi.org/10.1038/onc.2008.49 
[7] Geoerger B, Kerr K, Tang CB, et al: Antitumor activity of the rapamycin analog CCI-779 in human primitive neuroectodermal tumor/medulloblastoma models as single agent and in combination chemo-therapy. Cancer Res. 2001; 61: 1527-1532. PMid:11245461

[8] Karami M, Najafi F, Karami Matin B. Catastrophic Health Expenditures in Kermanshah, West of Iran: Magnitude and Distribution. JRHS. 2009; 9(2): 36-40. PMid:23344170

[9] Rostaei S, Ahadnejad Reveshty M, Asghari Zamani A, Zangenh A. Assessment of Urban Poverty Spatial Distribution in Kermanshah City. Social Welfare. 2012; 12 (45): 77-101.

[10] Shanzhi W, Yiping H, Ling H, Jianming Z, Qiang L. The Relationship between TTF-1 Expression and EGFR Mutations in Lung Adenocarcinomas. PLoS One. 2014 Apr 17; 9(4): e95479. PMid:24743427

http://dx.doi.org/10.1371/journal.pone.0095479

[11] Herbst RS. Review of epidermal growth factor receptor biology. Int J Radiat Oncol Biol Phys. 2004; 59(2 Suppl): 21-6. PMid:15142631 http://dx.doi.org/10.1016/j.ijrobp.2003.11.041

[12] Marchetti A, Martella C, Felicioni L, Barassi F, Salvatore S, Chella A, et al. EGFR mutations in non-small-cell lung cancer: analysis of a large series of cases and development of a rapid and sensitive method for diagnostic screening with potential implications on pharmacologic treatment. J Clin Oncol. 2005 Feb 1; 23: 857-65. PMid:15681531 http://dx.doi.org/10.1200/JCO.2005.08.043

[13] Weber B, Meldgaard P, Hager H, Wu L, Wei W, Tsai J, et al. Detection of EGFR mutations in plasma and biopsies from non-small cell lung cancer patients by allele-specific PCR assays. BMC Cancer. 2014 Apr 28; 14(1): 294. PMid:24773774 http://dx.doi.org/10.1186/1471-2407-14-294

[14] Politi K, Lynch TJ. Two sides of the same coin: EGFR exon 19 deletions and insertions in lung cancer. Clin Cancer Res. 2012 Mar 15; 18(6): 1490-2. PMid:22317760 http://dx.doi.org/10.1158/1078-0432.CCR-11-3282

[15] Chinnaiyan P, Huang S, Vallabhaneni G, et al: Mechanisms of enhanced radiation response following epidermal growth factor receptor signal- ing inhibition by erlotinib (Tarceva). Cancer Res. 2005; 65: 3328-3335. PMid:15833866

[16] Cohen RB, Janne PA, Engelman JA, et al. A phase I safety and pharma-cokinetic (PK) study of PI3K / TORC1/TORC2 inhibitor XL765(SAR245409) in combination with erlotinib (E) in patients (pts) with advanced solid tumors. J Clin Oncol. 2010; 28: A\#3015.

[17] Lynch TJ, Bell DW, Sordella R, et al: Activating mutations in the epidermal growth factor receptor under- lying responsiveness of non-small-cell lung cancer to gefitinib. N Engl J Med. 2004; 350: 2129-2139. PMid:15118073 http://dx.doi.org/10.1056/NEJMoa040938

[18] Ja "nne PA, Wang X, Socinski MA, et al. Randomized phase II trial of erlotinib alone or with carboplatin and paclitaxel in patients who were never or light former smokers with advanced lung adenocarcinoma: CALGB 30406 Trial. J Clin Oncol. 2012; 30: 2063-69. PMid:22547605 http://dx.doi.org/10.1200/JCO.2011.40.1315

[19] Ikeda K, Clark JC, Shaw-White JR, Stahlman MT, Boutell CJ, Whitsett JA. Gene structure and expression of human thyroid transcription factor-1 in respiratory epithelial cells. J Biol Chem. 1995 Apr 7; 270(14): 8108-14. PMid:7713914 http://dx.doi.org/10.1074/jbc.270.14.8108

[20] Moldvay J, Jackel M, Bogos K, Soltész I, Agócs L, Kovács G, et al. The role of TTF-1 in differentiating primary and metastatic lung adenocarcinomas. Pathol Oncol Res. 2004; 10(2): 85-8. PMid:15188024 http://dx.doi.org/10.1007/BF02893461

[21] Lee JS, Kim HR, Lee CY, Shin M, Shim HS. EGFR and TTF-1 gene amplification in surgically resected lung adenocarcinomas: clinicopathologic significance and effect on response to EGFR-tyrosine kinase inhibitors in recurred cases. Ann Surg Oncol. 2013 Sep; 20(9): 3015-22. PMid:23525704 http://dx.doi.org/10.1245/s10434-013-2937-2

[22] Vallee A, Sagan C, Le Loupp AG, Bach K, Dejoie T, Denis MG. Detection of EGFR gene mutations in non-small cell lung cancer: lessons from a single-institution routine analysis of 1,403 tumor samples. Int J Oncol. 2013 Oct; 43(4): 1045-51. PMid:23934203

[23] Porta R, Sánchez-Torres JM, Paz-Ares L, Massutí B, Reguart N, Mayo C, et al. Brain metastases from lung cancer responding to erlotinib: the importance of EGFR mutation. Eur Respir J. 2011 Mar; 37(3): 624-31. PMid:20595147 http://dx.doi.org/10.1183/09031936.00195609 
[24] Wilson CM, Gaber MW, Sabek OM, et al. Radiation-induced astrogliosis and blood-brain barrier damage can be abrogated using anti-TNF treatment. Int J Radiat Oncol Biol Phys. 2009; 74: 934-941. PMid:19480972 http://dx.doi.org/10.1016/j.ijrobp.2009.02.035

[25] Togashi Y, Masago K, Masuda S, Mizuno T, Fukudo M, Ikemi Y, et al. Cerebrospinal fluid concentration of gefitinib and erlotinib in patients with non-small cell lung cancer. Cancer Chemother Pharmacol. 2012 Sep; 70(3): 399-405. PMid:22806307 http://dx.doi.org/10.1007/s00280-012-1929-4 